\title{
New Zealand perspectives on early childhood education: Nāku te rourou nāu te rourou ka ora ai te iwi
}

\section{Marek Tesar}

Abstract: This special issue focuses on histories, pedagogies, policies, philosophies and alternative perspectives in early childhood education. Te Whäriki is heralded as the first bicultural curriculum not only in New Zealand, but in the world. Its importance is reflected in national and international research and early childhood discourses. Despite this, there is simultaneous critique of neoliberal policy, globalised practices and public and private investment in early childhood education in this region. Some lessons from New Zealand, of curriculum building, policy implementation, philosophies and sociologies of children and childhood are explored by New Zealand scholars, and focus on these broad New Zealand perspectives of ECE, to address the diverse interests of an international audience.

Key words: New Zealand, early childhood, teachers, policy, pedagogy.

Nāku te rourou nāu te rourou ka ora ai te iwi - 'With your basket and my basket the people will live', the Māori proverb can be translated into English to refer to the collaboration in a land geographically far away from any other land mass and country. This notion of pulling resources together relies on ideas of togetherness, and on narratives that have emerged from the historical collaborations and tensions between Māori, the indigenous peoples of Aotearoa New Zealand, and the settlers and immigrants, originally mostly from the British empire, but nowadays from all around the world. This Māori whakataukī (proverb) reminds us of the histories and of pulling together stories from the past, to be looking forward. It also sets a direc- 
tion for scholarship and experiences of Aotearoa New Zealand to be shared with scholars, teachers and student teachers in other countries, and allows the potentiality of learning from each other, while understanding how early childhood education needs to be contextualised with its ontological, epistemological, ethical and political concerns. Only within this understanding we can look foreward.

However, to look forward, it is important to understand history, or to historicise, as Foucault's work reminds us. As a colonialist settler state, Aotearoa New Zealand has a very specific history. Te Tiriti o Waitangi (The Treaty of Waitangi) was signed in 1840, and embedded key principles of partnership, protection and participation between Māori and the British Crown. In early childhood education, the development of Te Whäriki as a bicultural curriculum framework began in the early 1990s. Since its inception, the curriculum document has both witnessed and created a framework for resistance to continuing colonising and neoliberal ideologies. A strong focus on economic structures and individual rights, hegemonising and globalising practices, regulation and deregulation, have permeated the landscape of early childhood education in Aoteaora New Zealand.

\section{Early childhood education in Aotearoa New Zealand}

Every country defines and performs early childhood education differently, within frameworks of different policies and histories. In New Zealand, the landscape of early childhood education is very complex and convoluted and refers to the range of services and ideas that allow children, mostly under the age of 5, to be enrolled in early years services with diverse purposes, scope and focus on different philosophies and age groups. While the compulsory schooling age is 6 , the majority of children start school the day after their 5 th birthday, with only some staying in early years centres for longer. In recent statistics (OECD, 2015), most children, nearly $95 \%$ of 3 and 4 year olds, get some sort of exposure to early childhood education, on average for 20 hours per week (Ministry of Education, 2015), and 40\% of children under 3 years old. New Zealand early childhood education is governed by a number of bodies and policies, most notably by the Ministry of Education, quality assurance of teaching settings organisation, the Educational Review Office (ERO), the New Zealand Qualifications Authority (NZQA) that considers the levels and quality of qualifications, and the Education Council that governs teacher registration processes. A number of key policies have been developed in recent years in New Zealand that shape and regulate the sector, such as the national curriculum framework Te Whäriki (Ministry 
of Education, 1996) and the revised Education (Early Childhood Services) Regulations in 2008. Currently, with more than 4,000 early years settings in a country of less than 5 million people, the main categories of services are teacher led services where at least $50 \%$ of teachers must be qualified and registered early childhood teachers, and parent-led services such as Playcentres, Kohanga Reo and Playgroups. New Zealand has over 21,000 registered early childhood teachers, $98 \%$ of whom are female teachers (Education Council, 2015).

Early childhood education in Aotearoa New Zealand is grounded in an integration of education and care within the Ministry of Education, and in a clear separation from the compulsory schooling sector. While there has been continued in government spending on early childhood education in recent years, this spending needs to be considered in relation to the rapid growth in early childhood services, teachers, and children that are enrolled. Since the 1980s and the rise of neoliberalism, there has been a push for women to return back to the workforce and younger and younger children are entering services. Currently, infant and toddler education and growing enrolments of under 2 year olds has been one of the topics that has dominated the early years discourses. However, within the overall picture of early childhood education, despite positive statements by international scholars such as Moss $(2007,2008)$, there are many challenges and tribulations as illustrated by the papers in this special issue. May (2014), for instance, notes, "the statistics, however, reveal that not all children are beneficiaries of past policy initiatives. Government policy has classified some of these children as potentially 'vulnerable'; a 'risk' to society and a 'priority' for ECEC" (p. 154).

The release of this special issue coincides with the 20th anniversary of the release and wide implementation of Te Whäriki, which is widely regarded around the world and used as an exemplar as a for other. Te Whäriki aspires for children "to grow up as competent and confident learners and communicators, healthy in mind, body, and spirit, secure in their sense of belonging and in the knowledge that they make a valued contribution to society", who have relationships with "people, places and things" (Ministry of Education, 1996, p. 9). The curriculum uses the metaphor of the woven mat that allows all actors - teachers, children, whānau (family) and community to be engaged in the process of weaving curriculum knowledges. This curriculum framework does not set achievement standards, but uses aspirational statements that empower teachers to create the curriculum with children in any given community, allowing children to develop holistically, and create strong relationships and a sense of belonging. Te Whäriki allows us to see the world differently, to see the strengths in diversity and difference, to focus on a child's interests and to work closely with families and communi- 
ties. In a nutshell, in this very young country, this curriculum framework provides an aspirational ideal of 'how to live well together', with others, with the environment, with things, and it works with the historical heritage of Māori-Pakeha (settlers) relationships that dates back to the early 19th century (Jones \& Jenkins, 2011).

\section{Te Whāriki's childhoods}

Te Whäriki, as an early childhood curriculum framework, represents a partnership with Māori and Māori tikanga (values) and ideas, demonstrating the weaving that is represented by its methaphorical meaning, as the woven mat on which we can all stand. The development of Te Whäriki involved communities, scholars and early childhood teachers, at a time of neoliberal educational policies that were particularly focused on improving the lives of individuals and on developing the economy. These ideas have become increasingly dominant in early childhood education in Aotearoa New Zealand, elevating notions of choice, accountability, individual responsibility, and a focus on economic growth and business investment. The story of Te Whäriki is also a story of resistance (Tesar, 2015) as its strongly relational principles, strands and goals stand in the face of the neoliberal political climate. These relationships and politics are complex and have been well documented (May, 2009; Nuttall, 2013). Te Whäriki utilizes developmental and socio-cultural discourses (of Piaget, Erikson, Vygotsky, Bruner) and through the weaving metaphor, sets up a curriculum framework that is not dominated by one worldview of the child or childhood. This weaving model of learning conceptualizes childhood and the child's learning as multiple intricate and diverse patterns that link experience, development and meaning, centered equally on cultural and individual purposes. It accommodates diverse approaches, and in this way it provides for cultural and learner diversity, and for bicultural knowledges and understandings. As 'a mat for all to stand on' it encourages each setting and teacher to develop their own unique programme within the framework, to suit local cultural traditions and environments, and to support and cater for children's interests and aspirations.

The curriculum framework invites teachers to weave themselves, the children, their cultures and settings into the curriculum, and it encourages dialogue and reflection. The resistance inherent in Te Whäriki lies particularly in its language and non-prescriptive curriculum, as the political language of the era shifted from rights to risk and vulnerability, or as May (2014) argues "from investment in inputs to accounting of outputs." Nuttall (2013) summarises these concerns as early childhood education being "no longer seen 
as a public good but as a vehicle for risk minimisation for government, now and in the future ... The language of Te Whäriki is not one of risk, vulnerability and competition. It speaks, instead of opportunity, respect and relationships" (pp. 2-3). In this environment, children in early years centres are not subjected to formal tests or assessments, but are exposed to the formative approach that is characterised by the learning stories and other means of documenting learning, where children contribute to and proudly share their own portfolios.

A recent report by the Early Childhood Education Taskforce (2011) expresses concerns about Te Whäriki, and about its support of Māori and Pasifika children, and children with English as a second language. These concerns further perpetuate recent calls for measurable outcomes, clear guidelines, subject knowledge, and assessment practices that would prepare children for the future and for school. This shift can be conceived as a neo-colonisation of childhoods and children by institutions such as the OECD, implicating children in migrations from home to early childhood settings, so that women can return to a productive workforce. The nature of neoliberal and neo-colonialist policy, re-producing various histories, however. can equally well mean that these women end up in low paying jobs, which barely cover the ever-rising fees for increasingly privatised childcare. Attempts to measure Te Whäriki's effectiveness need, therefore, to embody the infinite intricacies and complexities implicated by these ideologies.

Early years centres in Aotearoa New Zealand are thus built on intersections of a colonial history, recent policy developments, and the growing number of business oriented, for-profit early years centres (May, 2009). These conditions have been influenced by women returning to the workforce, and the increased demand for more accessible services for parents. In the early 1990s, the bicultural curriculum framework Te Whäriki repositioned some of these spaces/places through its holistic thinking and child focus. Early years settings are not only embedded in the policy and discourse of early childhood, but their foundations can also be traced in the land and soil, in the materiality and things that surround and encompass the early years settings, as well as in global and local experiences (Duhn, 2012).

In 2015, the Education Review Office released a report Infants and toddlers: Confident and competent communicators and explorers, which provides an overview and an assessment of settings for under 2 year olds. What is interesting and intriguing about this report is that the teacher's qualifications, ratios and group sizes made no difference to the data that ERO has 
produced and released. Furthermore, the report pushes the responsibility, through its recommendations, on early childhood centres, and away from the governing agencies. This report is scrutinised in depth in the most recent issue of the First Years Journal (Cooper $\&$ Tesar, 2015). The other major report in 2015 was released by the Advisory Group on Early Learning that was established by the Ministry of Education, to examine ways to ensure a successful transition from early childhood education to school, and to explore potentialities for strengthening Te Whāriki. This report provided the sector with 20 recommendations, to be implemented within short, medium to long-term timeframes. The evaluations of this group led to recommendations to re-consider funding for professional development, to update $T e$ Whäriki, to enhance mentoring and induction for early childhood teachers, and other structuring and policy changes. The waters of Aotearoa New Zealand early childhood education never stay still.

\section{Narratives from Aotearoa New Zealand}

This special issue ${ }^{1}$ opens up with a foreword by a world leader in early childhood education and social justice, from Arizona State University, Professor Beth Blue Swadener. Her introduction and reflection opens up possibilities of what New Zealand early childhood education offers to world academe, theory and practice. Swadener talks about the "improbable possibilities and vision" that New Zealand scholarship has been producing and serving as a counterpoint and point of reference at the same time to the early childhood education and care in the global context. The paper by May, the first in this collection, gives this special issue an important framing by looking back to look forward, and provides insights into the history and politics of 19th century Aotearoa New Zealand. In her paper, she argues that "a blueprint had been established that shaped twentieth century early childhood initiatives and policies". And this is the blueprint that the other papers in this collection consider and work within in 20th century and contemporary early childhood education and care, "to rethink and redress our colonial heritage". Ritchie's paper asks how we can move "towards critical social, cultural, and ecological transformational capacity" in the time of the anthropocene, when particular "indigenous peoples' wellbeing is tied closely to the wellbeing of their land". These concerns highlight the ethical considerations that are embedded and linked with Māori onto-epistomologies. Her paper is an embodiment of weaving theory and practice that asks us how do "we challenge education that continues to normalise the politics of

This special issue is supported by VEGA $1 / 0057 / 15$ 
colonisation and globalisation", particularly through a lens of social justice and a focus on indigenous people, and marginalised and often overlooked discourses?

Farquhar delivers a powerful argument as she traces the politics of collaboration in which the curriculum framework Te Whariki is considered to be a "contestable political document". In her paper, that is strongly grounded in philosophy and educational theory, she argues that "our shared reality for continuous interrogation and experimentation - an attitude of critique that would involve curriculum-makers in a practice of freedom where freedom is in the very act of resistance". This argument of freedom is set against the notions of collaboration and control, micro and macro practices, and resistance, mixed in a complex political system of democracy in neoliberal ideology. Arndt and Tesar pick up on shifts in the early childhood sector in relation to changes and controversies in assessment beliefs and practices in Aotearoa New Zealand. Integrally connected and aligned with Te Whāriki, assessment shares its uncertainty, arising in the face of the recent government reports. This paper explicates and examines some of these contemporary issues, tensions, strengths and concerns. Gibbons' paper examines the often overlooked notion of "what it means to have health as a key part of the curriculum", as he traces health and wellbeing in Te Whäriki, utilising policy documents and a Foucauldian framework. He argues that "fixed ideas of health are a problem in the way such knowledge serves as the only kind of knowledge we can have about health and wellbeing, and about the whereabouts of health in the early childhood curriculum", as he analyses the relations between health and education. He calls for making "space for discussion and debate and action about different understandings of health". It is this call for scholarship and action, or thinking and doing, that papers in this special issue particularly respond to.

Gunn considers the concern of what it means, "to do research in early childhood education settings" in her paper. The researcher's narrative is the story of ethics and children's rights, and Gunn argues that "surely if we are to uphold children's participation rights in research then we must be concerned to report to children about the research process and the sense making that is coming from it". In her paper, she is thinking with and doing the "conceptualising research work as pedagogical/curriculum work". This paper presents an important caution and consideration for researchers to any research work with young children, and in this instance where the curriculum permeates the unusual and mundane of any early years setting. Arndt in her paper merges the philosophical thinking about subjects in process 
and the need to "reconceptualise the idea of knowing immigrant teacher subjects" in the globalised world with increased intercultural exchanges and experiences, and in particular the "confrontation and (re)negotiation of social, political and professional expectations and unknowable foreignness" of teachers that come from overseas to be in Aotearoa New Zealand. She uses a post-structuralist feminist lens through the work of Kristeva to explore the complexities of what it means to be a teacher. In her closing argument, she argues that "perhaps immigrant teachers' grapplings with their ongoing subjectifications, in their new location and teaching team, reveal more than their own pedagogical and cultural struggles". In the concluding paper in this collection, Craw argues for "making visible a deeper more complex engagement with (contemporary-) art-centred pedagogy and subject-content knowledge in (teacher-) education", and gives a fascinating narrative into the history and present of art-centered pedagogies in Aotearoa New Zealand through her rich personal experiences and analysis of contemporary discourses, where she hopes "to enact an inclusive yet open-ended relationship-based curriculum". In the final statement of her paper she claims, that "the history of art and education in New Zealand is rich. This richness is charged with very contemporary knowledges and understandings of art and of education that continue to have an impact in and on 21 st century understandings of art, if not in and on the future of art in education".

This special issue focuses on histories, pedagogies, policies, philosophies and alternative perspectives in early childhood education. Te Whāriki is heralded as the first bicultural curriculum not only in New Zealand, but in the world. Its importance is reflected in national and international research and early childhood discourses. Despite this, there is simultaneous critique of neoliberal policy, globalised practices and public and private investment in early childhood education in this region. The lessons from New Zealand, of curriculum building, policy implementation, philosophies and sociologies of children and childhood are explored by top New Zealand early years scholars in one single issue, focused on these broad New Zealand perspectives of early childhood education, to appeal to the diverse interests of an international audience. It is our hope that this special issue explores and examines the richness of Aotearoa New Zealand education, but also the complexities, depth, thoughts and struggles that are associated with early childhood education in Aotearoa New Zealand. What is evident in all of these papers, is that Nāku te rourou nāu te rourou ka ora ai te iwi is a proverb that depicts the early childhood education sector in Aotearoa New Zealand. Through this collection of work we hope to draw in also the 'knowledge baskets' of international readers, and that they will join the debates, discussions and conversations. 


\section{References}

Cooper, M., \& Tesar, M. (2015). Editorial: Infants and toddlers as competent and confident explorers in Aotearoa New Zealand? The First Years Journal, 17(2), 3.

Duhn, I. (2012). Places for pedagogies, pedagogies for places. Contemporary Issues in Early Childhood, 13(2), 99-107.

Early childhood education taskforce. (2011). An agenda for amazing children: Final report of the early childhood education taskforce. Wellington, NZ: Early Childhood Education Taskforce.

Education council. (2015). Fast facts. Retrieved from http://www.educationcouncil. org.nz/news-events/news/fast-facts.

Education review office. (2015) Infants and toddlers: Confident and competent communicators and explorers. Retrieved from http:/ /www.ero.govt.nz/National-Reports / Infants-and-toddlers-competent-and-confident-communicators-and-explorersJune-2015/Findings.

Jones, A., \& Jenkins, K. (2011). He kōrero. Words between us: First Māori-Pākeha conversations on paper. Wellington: Huia Publishers.

May, H. (2009). Politics in the playground. Dunedin, NZ: Otago University Press

May, H. (2013). Curriculum implementation in ECEC: Te Wharriki in international perspective. Paper presented at the NZ Conference on ECEC in co-operation with the OECD ECEC Network, December 2013, Wellington, Aotearoa New Zealand.

May, H. (2014). New Zealand: A Narrarive of shifting policy directions for early childhood education and care. In L. Gambaro, K. Stewart, \& J. Waldfogel (Eds.), An equal start?: Providing quality early education and care for disadvantaged children (pp. 171-192). Bristol, UK: Policy Press.

Ministry of Education. (1996). Te Whāriki: He Whāriki Mātauranga mō ngā Mokopuna o Aotearoa: Early Childhood Curriculum. Wellington, New Zealand: Learning Media.

Ministry of Education. (2015). Early learning. Retrieved from http://www.education. govt.nz/early-childhood/

Moss, P. (2007). Leading the wave: New Zealand in an international context. In Travelling Pathways to the Future - Ngā Huarahi Arataki (pp. 27-36). Early Childhood Education Symposium Proceedings, 2-3 May, Wellington, NZ: Ministry of Education. Moss, P. (2008). Childcare, markets and technical practice: Re-politicising early childhood'. In Proceedings of Early Childhood Care and Education Seminar, Series pp. 5-14. Dublin, Ireland: Centre for Social and Education Research.

Nuttall, J. (Ed.). (2003). Weaving Te Whāriki: Aotearoa New Zealand's early childhood curriculum document in theory and practice. Wellington, New Zealand, NZCER Press. OECD. (2015). Education at a Glance 2015. Retrieved from http://www.oecd.org/ education/education-at-a-glance-19991487.htm

Tesar, M. (2015). Te Whāriki in Aotearoa New Zealand: Witnessing and Resisting Neoliberal and Neo-colonial Discourses in Early Childhood Education. In V. PaciniKetchabaw, \& A. Taylor (Eds.), Unsettling the Colonial Places and Spaces of Early Childhood Education (pp. 145-170). London, UK: Routledge. 


\section{Author:}

Marek Tesar, Ph.D.

University of Auckland

Faculty of Education and Social Work

Department School of Learning, Development and Professional Practice

78 Epsom Avenue

Auckland

1035

New Zealand

Email: m.tesar@auckland.ac.nz 